\title{
REVITALISASI KAWASAN WISATA PESISIR SAMAS, KABUPATEN BANTUL
}

\author{
Afid Nurkholis ${ }^{1}$, Amalya Suci W ${ }^{1}$, Ardian Abdillah $^{1}$, Arum Sari Widiastuti ${ }^{1}$, Ayu Dyah Rahma ${ }^{1}$, \\ Deka Ayu Maretya ${ }^{1}$, Gina Aprila Wangge ${ }^{1}$, Yuli Widyaningsih ${ }^{1}$ \\ ${ }^{1}$ Departemen Geografi Lingkungan, Fakultas Geografi, Universitas Gadjah Mada, Yogyakarta \\ Email: afidnurkholis@gmail.com
}

\begin{abstract}
Abstrak
Pesisir merupakan salah satu kawasan yang memiliki dinamika tinggi. Pantai Samas merupakan kawasan wisata pesisir yang terletak di Desa Srigading, Kecamatan Sanden, Kabupaten Bantul. Dinamika pesisir yang cenderung berdampak negatif mengakibatkan Pesisir Samas saat ini memiliki permasalahan utama berupa jumlah pengunjung yang sangat sedikit. Penelitian ini akan mengkaji penyebab degradasi lingkungan, upaya pengelolaan lingkungan yang telah dilakukan, dan rekomendasi strategi revitalisasi Pesisir Samas yang tepat. Data yang digunakan berupa primer dan sekunder dengan teknik pengamilan data melalui observasi lapangan dan wawancara mendalam dengan beberapa narasumber. Analisis data dilakukan dengan diskriptif kualitatif dan kuantitatif. Hasil penelitian menunjukkan bahwa penyebab penurunan pengunjung Pesisir Samas adalah adanya abrasi dan banjir besar, degradasi sosial berupa maraknya PSK, dan dibukanya kawasan wisata pesisir lain yang lebih menarik. Pengelolaan lingkungan yang telah dilakukan berupa penanaman cemara udang, pembuatan daya tarik baru berupa Wisata Pengklik, pembangunan kembali bangunan konservasi penyu, dan penghapusan kegiatan PSK. Meskipun demikian, pengelolaan yang telah dilakukan masih belum optimal. Oleh karena itu, strategi revitalisasi baru perlu dilakukan untuk mengembalikan kejayaan Pesisir Samas seperti sediakala. Rekomendasi tersebut berupa Zonasi Pesisir Samas yang berlandaskan keberlanjutan, penguatan organisasi masyarakat yang didukung pemerintah, akademisi, dan korporat, serta promosi wisata Pesisir Samas.
\end{abstract}

Katakunci: degradasi lingkungan, pengelolaan lingkungan, pesisir, strategi revitalisasi, Pantai Samas, zonasi pesisi

\section{$\underline{\text { Sitasi model APA }}$}

Nurkholis, A., Rahma, A. D., Widyaningsih, Y., Maretya, D. A., Wangge, G. A.,... Abdillah, A. (2016, June 11). REVITALISASI KAWASAN WISATA PESISIR SAMAS, KABUPATEN BANTUL. http://doi.org/10.17605/OSF.IO/F7HQC 


\section{Pendahuluan}

\subsection{Latar Belakang}

Pesisir merupakan salah satu kawasan yang memiliki dinamika tinggi. Strahler (2011) menyatakan bahwa pemanasan global telah meningkatkan kerentanan pesisir terhadap terjadinya bencana. Pemanasan global akan memicu terjadinya kenaikan muka air laut, badai, erosi pantai, dan anomali iklim seperti EL Nino dan La Nina yang semakin intensif terjadi (Garrison, 2011). Pantai Samas merupakan kawasan wisata pesisir yang terletak di Desa Srigading, Kecamatan Sanden, Kabupaten Bantul. Pantai ini memiliki daya tarik berupa hamparan gisik yang luas, laguna dari muara Sungai Opak, dan sebagai tempat bertelurnya penyu. Dinamika pesisir yang cenderung berdampak negatif mengakibatkan Pantai Samas saat ini memiliki permasalahan utama berupa jumlah pengunjung yang sangat sedikit.

Bencana abrasi yang terjadi di Pantai Samas pada tahun 2013 merupakan salah satu contoh dinamika negatif. Abrasi tersebut diperparah dengan kondisi laguna yang tersendat, sehingga menyebabkan air laut tidak dapat bertemu dengan air sungai. Hal ini memicu berpindahnya muara Sungai Opak ke kawasan pemukiman sehingga bencana banjir terjadi (Saputra dkk, 2013). Pantai Samas merupakan kawasan yang memiliki dampak abrasi dan banjir paling parah di pesisir Bantul pada tahun 2013 (BPBD, 2013). Dampak adanya abrasi dan banjir Sungai Opak adalah sebagai berikut (BPBD, 2013).

(1) Daratan bergeser dan berubah menjadi laut sekitar 500 meter dari bibir pantai awal dan terdapat sekitar 50 warga mengungsi.

(2) Terendamnya lahan pertanian padi seluas 4 ha di sebelah timur permukiman Samas.

(3) Tergangungnya aktivitas melaut para nelayan.

(4) Dua puluh satu bangunan milik pemerintah hilang dan rusak termasuk tempat pelelangan ikan dan konservasi penyu serta 19 rumah rusak.

(5) Terganggunya struktur sosial masyarakat, disorganisasi sosial, disintegrasi sosial, dan dapat mengarah pada konflik.

(6) Terganggunya aktivitas pariwisata yang ada.

Pariwisata merupakan kegiatan ekonomi tersier yang seharusnya dapat meningkatkan kesejahteraan masyarakat sekitar (Fouberg dkk, 2012). Keindahan alam Pantai Samas pada dasarnya dapat memicu tumbuhnya perekonomian dengan adanya jasa pedagang, pemandu wisata, tempat bermain, dan retribusi masuk. Meskipun demikian, Pantai Samas memiliki jumlah pengunjung yang selalu berkurang setiap tahun Hal ini tentunya merugikan bagi masyarakat sekitar, sehingga langkah-langkah strategis perlu segera dilakukan untuk mengoptimalkan potensi sumberdaya alam ini. Oleh karena itu, revitalisasi Pantai Samas perlu segera dilakukan untuk mengembalikan kejayaan seperti sediakala. 


\subsection{Tujuan}

Berdasarkan latar belakang masalah diatas, tujuan dari penelitian ini dapat disusun sebagai berikut.

1. Menganalisis penyebab penurunan pengunjung Pantai Samas.

2. Menganalisis pengelolaan lingkungan yang telah dilakukan di Pantai Samas.

3. Melakukan rekomendasi strategi revitalisasi Pantai Samas agar menjadi destinasi wisata yang menarik kembali.

\section{Kajian Pustaka}

\subsection{Pesisir}

Wilayah pesisir menurut Nontji (2002) yaitu wilayah pertemuan antara laut dan daratan, daerah daratan mencakup daerah yang masih dipengaruhi oleh aktivitas air laut seperti pasang surut, angin laut, dan intrusi garam, sedangkan daerah lautan mencakup daerah laut yang masih dipengaruhi oleh proses alami yang ada di darat seperti sedimentasi dan aliran air tawar serta daerah yang masih dipengaruhi oleh aktivitas manusia di daratan. Menurut UU No. 27 tahun 2007 tentang batasan wilayah pesisir bahwa daerah daratan mencakup wilayah administrasi daratan dan ke arah laut sejauh 12 mil laut diukur dari garis pantai ke arah laut lepas dan/atau kearah perairan kepulauan. Wilayah pesisir merupakan wilayah yang unik karena merupakan tempat percampuran antara aktivitas daratan dan lautan, hal ini tentu mempengaruhi kondisi fisik yang pada umumnya pada daerah di sekitar laut memiliki kontur yang relatif datar. Kondisi tersebut sangat mendukung dalam pengembangan wilayah pesisir yang begitu potensial untuk dijadikan sebagai sumber mata pencaharian warga setempat.

\subsection{Pariwisata Pantai}

Pariwisata merupakan salah satu sektor industri yang bertujuan untuk meningkatkan pendapatan ekonomi masyarakat, perluasan kesempatan kerja, dan memperkenalkan keindahan alam kepada masayarakat lokal maupun internasional (Amin, 2011). Kegiatan pariwisata disekitar pantai memanfaatkan sumberdaya pantai dan permukaan air laut (Kusharjani dkk, 2009), sehingga kawasan pariwisata pantai didominasi oleh aktivitas masyarakat lokal maupun pendatang. Aktivitas tersebut adalah budidaya, perdagangan, dan jasa. Ketiga kegiatan tersebut memanfaatkan potensi alam untuk meningkatkan kesejahteraan. Sarana dan prasarana yang menunjang dibutuhan untuk menunjang kegiatan pariwisata sehingga menjadi daya tarik wisatawan.

\subsection{Degradasi Lingkungan}

Degradasi didefinisikan sebagai kondisi kerusakan dan penurunan kualitas lingkungan akibat intervensi manusia dan kegiatan pembagunan yang dicirikan dengan tidak berfungsinya komponen-komponen lingkungan (modul USU: Degradasi Lingkungan). Degradasi dibedakan atas 2 jenis, yaitu degradasi fisik dan degradasi sosial. 
Minimal ada 3 faktor yang mempengaruhi degradasi suatu lingkungan, yaitu faktor peningkatan jumlah penduduk, konspirasi perusahaan, dan kebijakan yang menekankan pada pertumbuhan ekonomi hingga menyebabkan perubahan penggunaan lahan dan degradasi fungsional suatu wilayah serta eksploitasi sumberdaya.

\subsection{Degradasi Lingkungan Fisik Pesisir}

Degradasi lingkungan fisik pesisir merupakan kondisi kerusakan dan penurunan kualitas lingkungan fisik disekitar pesisir, termasuk kondisi air, lahan dan udara. Kerusakan wilayah pesisir disebabkan oleh beberapa faktor, diantaranya pencemaran minyak, sampah, abrasi pantai, banjir, sedimetasi dan kerusakan mangrove serta terumbu karang. Kondisi degradasi wilayah pesisir ini diperparah oleh adanya aktivitas manusia, seperti pembukaan hutan manggrove untuk dijadikan tambak udang, penggunaan plastik dan pestisida, eksploitasi sumber daya alam yang berlebihan dan sebagainya.

\subsection{Degradasi Lingkungan Sosial Pesisir}

Degradasi lingkungan sosial pesisir merupakan kondisi kerusakan dan penurunan kualitas lingkungan sosial disekitar pesisir, termasuk kondisi interaksi dan edukasi serta sosial budaya. Secara umum degradasi sosial dipicu oleh 5 hal, yaitu pendidikan, lingkungan, keagamaan, teknologi, dan ekonomi (Suabuana, 2008). Masing-masing faktor saling mempengaruhi. Pendidikan yang rendah berdampak pada akses ekonomi yang sulit. Individu tanpa keterampilan dan himpitan ekonomi cenderung mudah melakukan tindak amoral atau kriminal untuk dapat memenuhi kebutuhannya. Tindakan amoral individu juga didorong oleh rendahnya nilai dan pengetahuan keagamaan individu tersebut. Teknologi dan lingkungan berperan dalam proses pencampuran kebudayaan (akulturasi budaya). Proses akulturasi budaya berdampak negatif, salah satunya menghilangkan sifat ketimuran pada diri individu.

\section{Metode Penelitian}

Metode penelitian memuat deskripsi wilayah, teknik pengambilan data, teknik analisis data, dan luaran penelitian. Beberapa tahapannya dijelaskan sebagai berikut.

\subsection{Deskrsipsi Wilayah}

\subsubsection{Desa Srigading}

Wilayah Pesisir Samas terletak di Desa Srigading Kecamatan Sanden Kabupaten Bantul DIY. Berdasarkan Peta RBI lembar Bantul Lembar 1408-221 Skala 1:25.000 Desa Srigading terletak pada Zona 49 S X : 418900-421650 dan Y : $9114500-9120000$ dengan sistem koordinat Universal Transverse Mercator (UTM) Datum WGS 1984. Desa Srigading meiliki luas wilayah mencapai $7345325 \mathrm{~m}^{2}$. Desa Srigading dibatasi oleh Desa Tirtohargo, Tirtosari dan Parangtritis di sebelah Timur, sebelah Utara dibatasi oleh Desa Sidomulyo, Tirtomulyo dan Caturharjo, sebelah Barat dibatasi oleh Desa Gadingharjo dan Gadingsari sedangkan sebelah selatan dibatasi oleh Samudera Hindia. 


\subsubsection{Komponen Fisik}

Desa Srigading memiliki kemiringan lereng antara 0-6\% dengan ketinggian mencapai 50 meter. Kondisi iklim di Desa Srigading ditunjukkan dengan jumlah curah hujan rerata tahunan 635-1500 mm dan suhu mencapai 29-30 ${ }^{\circ} \mathrm{C}$. Berdasarkan Peta Geologi Yogyakarta 1408-2 dan 1407-5 Skala 1:100.000 Desa Srigading terletak pada Endapan Vulkanik Gunung Merapi Muda (Qmi). Proses yang dominan terjadi adalah aktivitas marin dan fluvial. Hal ini menyebabkan Desa Srigading memiliki konfigurasi bentuklahan asal proses marin dan fluvial. Bentuklahan yang terdapat di Desa Srigading secara berurutan dari Selatan-Utara yaitu gisik, laguna, pesisir, dataran fluviomarin, dan dataran fluvial. Kondisi tanah yang berada di Desa Srigading termasuk kedalam Ordo Typic dan Vertic. Jenis tanah yang terdapat di darah kajian yaitu Typic Eutropepts, Typic Hydraquents, Typic Tropaquepts, Typic Ustipsamments, Vertic Eutropepts, dan Vertic Tropaquepts yang tersebar secara tidak merata. Kondisi jenis tanah yang sedemikian rupa membentuk tekstur tanah geluh, geluh berpasir di wilayah pesisir, dataran fluviomarin dan dataran fluvial serta tekstur pasir halus di sebelah selatan khususnya di bentuklahan gisik.

\subsubsection{Komponen Sosial}

Berdasarkan data dari Kecamatan Sanden Dalam Angka 2015, jumlah penduduk Desa Srigading 9.245 jiwa dengan 4.552 jiwa penduduk laki-laki dan 4.693 jiwa perempuan. Kepadatan penduduk mecapai $1220 \mathrm{jiwa} / \mathrm{km}^{2}$. Kondisi sosial ekonomi di wilayah ini digambarkan oleh tingkat penididikan dimana 39,71\% tamat SD, 24,35 tamat SMP, 28,81 tamat SMA dan 7,12 tamat D1-S3. Jenis Lapangan pekerjaan pada sektor primer yaitu sektor agrikultur. Jenis mata pencaharian tertinggi yaitu petani dengan persentase mencapai 57,73\%, Swasta 14,07\%, PNS 9,85\%, Pertukangan 7,62\%, Jasa 3,73\%, Nelayan 2,99\%, Pensiunan 2,28\% dan ABRI 1,73\%. (Adenan,2002). Potensi Pariwisata yang terdapat di Desa Srigading yakni Pantai Sama. Pantai yang berada di Desa Srigading terutama Samas merupakan wilayah yang merupakan pantai dengan pasir besi putih dan berwarna keabu-abuan dengan kemiringan datar. Pantai Samas saat ini berdasarkan survey lapangan 2015 dikembangkan menjadi pariwisata yang terbagi ke dalam wisata kuliner di Pengklik, wisata Pantai Samas dan terdapat wisata penangkaran Penyu. Pantai Samas sendiri juga dijadikan sebagai tempat untuk Upacara Kirab Tumuruning Mahesa Suro yang merupakan acara adat untuk mengenang Mahessa Suro.

\subsection{Jenis Data}

Data yang digunakan terdiri dari primer dan sekunder. Data primer yang digunakan berupa karakteristik fisik pesisir, kondisi degradasi sosial, dan kondisi degradasi fisik. Data 
sekunder yang digunakan berupa jumlah pengunjung Pantai Samas dan kebijakan pengelolaan lingkungan kawasan pesisir.

\subsection{Teknik Pengambilan Data}

Data primer didapatkan dengan melakukan obervasi lapangan dan wawancara mendalam dengan key person. Observasi lapangan dilakukan untuk mendapatkan gambaran karakteristik fisik (geomorfologi) dan dampak adanya degradasi lingkungan. Wawancara mendalam dilakukan untuk mendapatkan informasi mengenai dampak. Wawancara dilakukan terhadap tiga responden, yaitu: Pak Rujito (Pengelola Konservasi Penyu), Pak Bowo (Pengelola Wisata Pengklik), dan Pak Tridaryanto (Anggota Kelompok Nelayan).

Data sekunder didapatkan melalui studi litelatur dan wawancara. Studi literatur dilakukan untuk mendapatkan data jumlah pengunjung dan dampak degradasi lingkungan. Wawancara dilakukan terhadar Dinas Pariwisata Kabupaten Bantul untuk mendapatkan data kebijkakan pengelolaan wisata yang telah dan akan dilakukan.

\subsection{Teknik Analisis Data}

Analisis data dilakukan secara deskriptif kualitatif dan kuantitatif. Analisis secara deskriptif kualitatif dilakukan dengan cara mendeskripsikan penyebab menurunnya pariwisata di Pantai Samas. Penyebabnya dilihat dari beberapa faktor seperti abrasi, banjir Sungai Opak, menjamurnya Pekerja Seks Komersial, pembangunan jembatan, dan wisata pantai di sekitar Pantai Samas.

Analisis secara deskriptif kuantitatif digunakan untuk mengetahui besarnya penurunan jumlah pengunjung Pantai Samas. Deskripsi kuantitatif dilakukan dengan cara mencari data temporal jumlah pengunjung Pantai Samas sehingga dapat diketahui fluktuasinya. Perbandingan angka jumlah pengunjung dari tahun ke tahun dapat menunjukkan besarnya daya tarik Pantai Samas terhadap pengunjung.

Rekomendasi revitalisasi Kawasan Wisata Pesisir Samas dilakukan dengan cara menganalisis penyebab menurunnya pengunjung wisata dan pengelolaan lingkungan yang telah dilakukan. Dua data tersebut dijadikan dasar analisis kebijakan revitalisasi yang tepat.

\subsection{Luaran Penelitian}

Penelitian ini diharapkan dapat memberi informasi lebih lanjut tentang degradasi lingkungan dan upaya pengelolaan yang telah dilakukan di Kawasan Wisata Pesisir Samas. Selain itu, penelitian ini akan memeberi masukan berupa upaya pengelolaan Kawasan Wisata Pesisir Samas dan strategi revitalisasi yang dapat diterapkan untuk mengembalikan kejayaan Kawasan Wisata Pesisir Samas. 


\section{Hasil dan Pembahasan}

\subsection{Penyebab Menurunnya Pariwisata Pantai Samas}

Pantai Samas yang berada di pesisir selatan Bantul, DIY adalah salah satu destinasi wisata yang sangat terkenal sekitar tahun 1970-an. Pantai Samas menduduki peringkat kedua setelah Pantai Parangtritis, namun terdapat selisih pengunjung yang sangat banyak antara keduanya menurut data pengunjung dari Dinas Pariwisata Bantul (Tabel 1).

Tabel 1. Data Pengunjung Pantai Samas dan Pantai Parangtritis

\begin{tabular}{|c|c|c|}
\hline Tahun & Pantai Parangtritis & Pantai Samas \\
\hline 2006 & 795.432 & 27.095 \\
\hline 2007 & 948.871 & 42.941 \\
\hline 2008 & 1.196 .771 & 43.757 \\
\hline 2009 & 1.323 .857 & 35.173 \\
\hline 2010 & 1.162 .305 & 36.256 \\
\hline 2011 & 1.325 .853 & 51.900 \\
\hline 2012 & 1.783 .178 & 59.620 \\
\hline 2013 & 1.693 .340 & 60.650 \\
\hline 2014 & 1.879 .000 & 140.850 \\
\hline 2015 & 1.999 .870 & \\
\hline
\end{tabular}

Sumber: Sektor Pariwisata, Seni, dan Budaya APBD Kabupaten Bantul

Menurut data pengunjung pantai di atas, diketahui bahwa jumlah pengunjung Pantai Samas lebih sedikit jumlahnya dibandingkan Pantai Parangtritis dan mengalami kenaikan dan penurunan setiap tahunnya. Pada tahun 2010-2011, jumlah pengunjung Pantai Samas mengalami penurunan pengunjung karena Pantai Samas ini mulai kehilangan pesona keindahannya. Jumlah pengunjung di Pantai Samas juga memiliki jumlah yang sangat berbeda jauh dengan Pantai Parangtritis disebabkan karena adanya berbagai hal yang menurunkan pariwisata di Pantai Samas. Faktor-faktor yang menyebabkan menurunnya pariwisata di Pantai Samas meliputi abrasi dan banjir Sungai Opak, pembangunan jembatan dan pengembangan wisata lain di sekitarnya, serta adanya degradasi sosial (PSK) yang menjamur di Pantai Samas yang semakin memperburuk citra Pantai Samas. 
Abrasi merupakan kejadian musiman. Abrasi adalah siklus tahunan yang dipengaruhi oleh kondisi angin. Menurut penuturan narasumber, biasanya kejadian abrasi ini berlangsung pada musim kemarau yaitu pada bulan Oktober-Maret. Pantai Samas adalah salah satu pantai yang terbuka sehingga sangat mudah terjadinya abrasi secara alami. Proses abrasi yang terjadi di Kabupaten Bantul disebabkan karena adanya reklamasi untuk permukiman dan adanya kegiatan penambangan pasir. Karakteristik pantai ini memiliki tingkat pasang surut mencapai 1,3 m pada bulan Januari-Desember berdasarkan Dinas Hidro-Oseanografi TNI AL. Kemiringan pantai yang tergolong datar dengan tinggi gelombang yang cukup tinggi yaitu sekitar $3 \mathrm{~m}$ menyebabkan intensifnya proses abrasi di Pantai Samas.

Selain adanya proses abrasi, banjir dari Sungai Opak juga sering melanda di sekitar Pantai Samas. Hal ini disebabkan karena muara Sungai Opak yang tersendat dan adanya laguna di bagian timur Pantai Samas. Kondisi-kondisi tersebut menyebabkan potensi wisata Pantai Samas mengalami penurunan jumlah pengunjung dan berdampak pada lingkungan sekitar, antara lain sebagai berikut (BPBD, 2013).

a) Daratan bergeser dan berubah menjadi laut sekitar 500 meter dari bibir pantai awal dan terdapat sekitar 50 warga mengungsi.

b) Terendamnya lahan pertanian padi seluas 4 ha di sebelah timur permukiman Samas.

c) Tergangungnya aktivitas melaut oleh nelayan.

d) Dua puluh satu bangunan milik pemerintah hilang dan rusak termasuk tempat pelelangan ikan dan konservasi penyu serta 19 rumah hilang dan terancam.

e) Terganggunya struktur sosial masyarakat, disorganisasi sosial, disintegrasi sosial, dan bisa mengarah pada konflik.

f) Terganggunya aktivitas pariwisata yang ada.

Abrasi di Pantai Samas sebenarnya telah dianggap sebagai hal yang biasa terjadi dan tidak mengganggu kehidupan sosial ekonomi masyarakat setempat. Namun, terjadinya abrasi di pesisir Samas pada tahun 2013 menjadi abrasi yang cukup meresahkan masyarakat setempat karena abrasi disertai dengan luapan Sungai Opak. Kondisi tersebut diperparah oleh intervensi manusia dengan adanya kegiatan pembukaan jalur pengairan di muara untuk pertanian bawang merah.

Konservasi penyu di kawasan pesisir Samas berdiri sejak tahun 2000 dan dikelola oleh Pak Rudjito dibantu oleh masyarakat sekitar. Awalnya konservasi penyu dibangun dengan tujuan untuk menyelamatkan penyu yang terluka dan menyediakan tempat bertelur/berkembangbiak yang aman serta sebagai wahana wisata pendidikan. Konservasi penyu yang dibangun Pak Rudjito ini menjadi pelopor munculnya kelompok-kelompok konservasi penyu di pesisir selatan Bantul. Adanya abrasi dan banjir di pesisir Pantai Samas yang parah pada tahun 2013 menyebabkan area konservasi ini rusak. Hal ini tentu menyebabkan kerugian dan menyebabkan masyarakat tidak dapat melanjutkan kegiatannya dalam konservasi penyu. 
Wisata Pantai Samas berdiri sekitar tahun 1985, merupakan kawasan wisata yang pertama dibangun di pesisir selatan. Wisata Pantai Samas awalnya dibangun oleh pemerintah yang kemudian diserahkan kepada masyarakat untuk dikelola oleh kelompok nelayan dan masyarakat sekitar pesisir. Namun saat ini kejayaannya sudah tidak lagi terdengar karena merosotnya pengunjung pantai samas. Menurut penuturan Bapak Tridaryanto selaku anggota Pokdarwis Pantai Samas, hal tersebut terjadi karena dibangunnya jembatan parangtritis pada tahun berikutnya yang memberikan akses baru menuju pesisir selatan sehingga mimicu pertumbuhan obyek wisata pantai di pesisir selatan seperti Pantai Depok, Pantai Goa Cemara, Pantai Baru, dan lain-lain. Tumbuhnya obyek wisata pantai yang baru lebih menarik perhatian pengunjung menyebabkan berkurangnya pengunjung wisata pantai samas.

Selain faktor-faktor yang telah dijelaskan sebelumnya, penurunan pariwisata Pantai Samas juga disebabkan karena adanya degradasi sosial yang terjadi karena banyak warga pendatang di Pantai Samas yang membawa penyakit sosial seperti tumbuhnya wisata malam serta berjamurnya PSK. Hal tersebut menyebabkan pengunjung berpikir dua kali untuk berwisata ke Pantai Samas. Prostitusi merupakan suatu fenomena yang sudah tidak lagi dianggap tabu dalam kehidupan bermasyarakat. Edlund dan Korn (2002) menyebutkan bahwa prostitusi adalah sebuah pekerjaan yang dilakukan oleh wanita yang memiliki ketrampilan rendah untuk mendapatkan gaji yang tinggi. Fenomena prostitusi di Pantai Samas memang tidak mendominasi, namun keberadaannya cukup meresahkan penduduk sekitar.

Fenomena prostitusi di Pantai Samas menimbulkan pro dan kontra bagi penduduk sekitar karena fenomena ini dapat menimbulkan kerugian dan keuntungan bagi penduduk sekitar. Keuntungan bagi penduduk sekitar dengan adanya prostitusi antara lain penduduk setempat dapat memperoleh penghasilan tambahan sebagai penjual makanan dan minuman di tempat prostitusi, menyewakan rumah atau gubuknya untuk dikembangkan menjadi tempat prostitusi, dan penjaga keamanan serta tukang parkir bagi para tamu yang datang. Sementara kerugian akibat adanya fenomena prostitusi ini adalah semakin menurunnya wisatawan yang mengunjungi Pantai Samas kecuali pengunjung pada malam hari yang ingin menikmati jasa prostitusi dan menimbulkan kebisingan bagi warga sekitar pada saat malam hari.

\subsection{Upaya Pengelolaan Pantai Samas}

Upaya pengelolaan Pantai Samas yang telah dilakukan sebagai berikut.

\section{a. Penanaman Cemara Udang}

Penanaman cemara udang disekitar kawasan pesisir samas (Gambar 1) dikoordinasi oleh pemerintah. Penanaman cemara udang ini merupakan inisiatif dari pemerintah sebagai upaya penanggulangan kejadian abrasi disekitar pantai selatan. Cemara udang selain dapat mencegah abrasi, juga dapat digunakan untuk mencegah tsunami (republika.co.id). 
Cemara udang sangat cocok ditanam dikawasan pesisir atau lahan dengan tekstur pasiran. Menurut Tri Wahyu, Sekretaris BLH, fungsi cemara udang selain sebagai tanggul alam juga berfungsi untuk memperbaiki ekosistem pesisir yang telah rusak. Penanaman cemara udang ini merupakan bentuk konservasi dan pengelolaan kawasan pesisir.

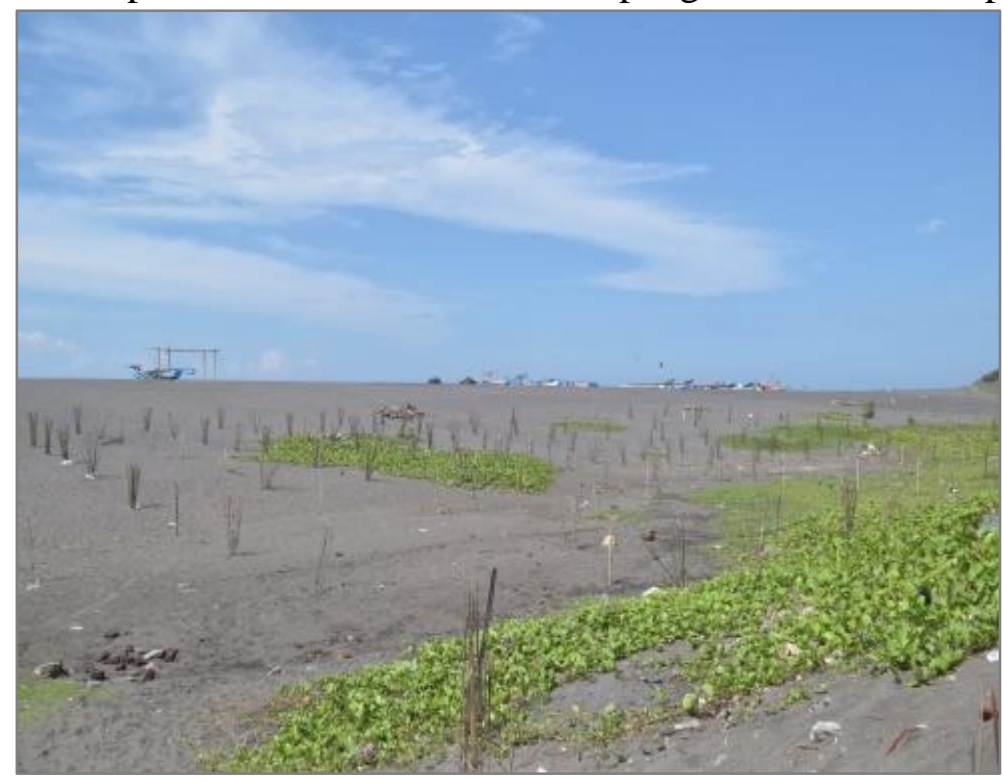

Gambar 1. Penanaman cemara udang di Pesisir Samas

Cemara udang dipilih karena pohonnya cukup rindang sehingga dapat digunakan untuk berteduh. Menurut sejarahnya dalam merdeka.com, cemara udang telah diuji coba ditanam sejak lama di kawasan pesisir selatan. Cemara jenis udang ini dibawa oleh Tim UGM dari madura. Tim UGM sebelumnya sempat menguji coba menanam tanaman jenis lain, seperti nyamplung dan ketapang, namun tidak pernah dapat hidup atau bertahan karena jenis tanaman tersebut tidak dapat hidup di kawasan dengan kadar garam tinggi. Hingga pada akhirnya cemara udang dari madura inilah yang dapat tumbuh subur di kawasan tersebut.

Tri Wahyu dalam republika.co.id menyebutkan bahwa penghijauan kawasan pesisir tidak hanya dilakukan dengan penanaman cemara udang saja, namun juga disertai penanaman pandan jenis tertentu yang dapat hidup di kawasan pesisir. Pandan jenis ini juga memiliki fungsi yang sama seperti cemara udang, yaitu tahan terhadap abrasi.

\section{b. Pembentukan Wisata Pengklik}

Wisata Pengklik merupakan wisata baru yang berada di kawasan pesisir samas (Gambar 2). Wisata ini pada mulanya dikelola oleh Dinas Kelautan dan Perikanan, hingga pada akhirnya diserahkan pada Badan Usaha Milik Desa untuk dikelola masyarakat. Wisata ini terdiri atas 2 jenis wisata, yaitu wisata pengklik dengan ikon utamanya berupa wisata perahu meyusuri laguna hingga ke pantai-pantai terdekat dan wisata kuliner dengan ikon utamanya berupa warung apung.

Wisata pengklik saat ini belum dapat berjalan optimal. Pelaksanaannya terkendala kondisi sarana prasarana wisata yang belum memadai. Dinas Kelautan dan Perikanan sebagai badan yang mengkoordinasi berjalannya wisata ini masih terus berupaya melengkapi 
sarana prasarana tersebut. Hasil wawancara dengan pengelola pengklik dijelaskan, tujuan dari dijalankannya usaha wisata pengklik ini adalah untuk mengembalikan kejayaan Samas sebagai tempat wisata dan memberdayakan masyarakat desa. Hal ini sesuai dengan apa yang disampaikan Edy Mahmud, Kepala Dinas Kelautan dan Perikanan Kab.Bantul dalam m.inilah.com, bahwa tujuan pengelolaan wisata samas ini tidak untuk peningkatan PAD (Pendapatan Asli Daerah), namun untuk meningkatkan kesejahteraan masyarakat pesisir dan pengembangan kawasan Samas.

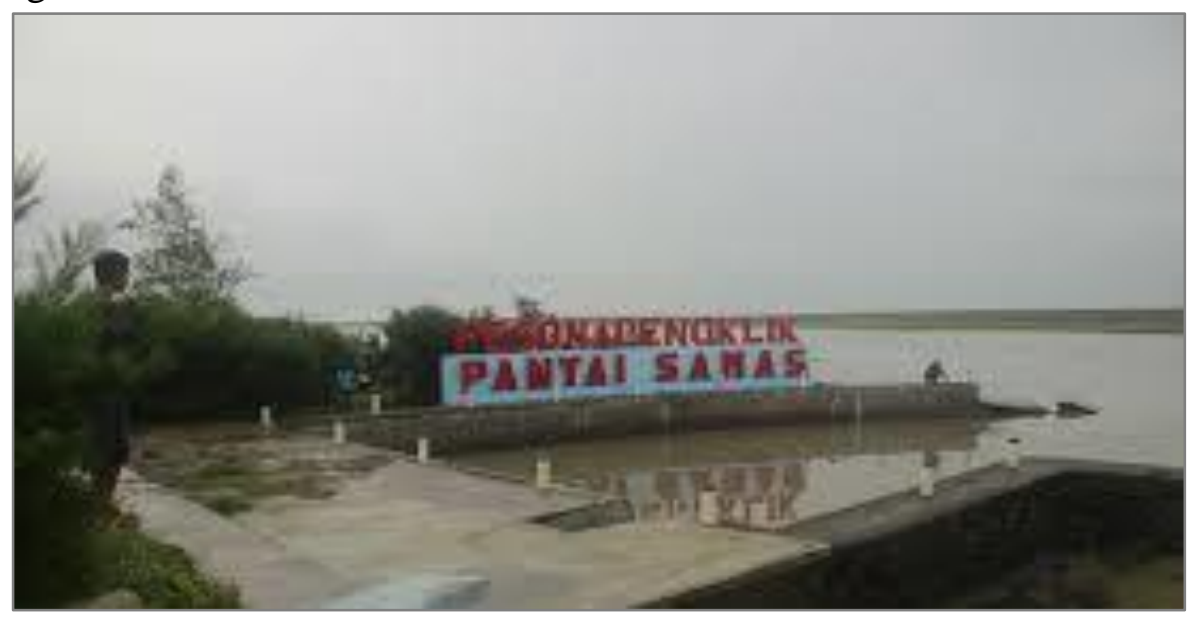

Gambar 2. Wisata Pengklik di Pesisir Sama

\section{c. Pembangunan Kembali Konservasi Penyu}

Konservasi penyu kawasan Pesisir Samas diinisiatori dan dikelola oleh Pak Rudjito dan masyarakat sekitar. Konservasi penyu ini dijalankan mengingat samas merupakan salah satu spot peneluran penyu. Hal ini terlihat dari banyaknya penyu yang mendarat di pesisir ketika musim bertelur tiba.

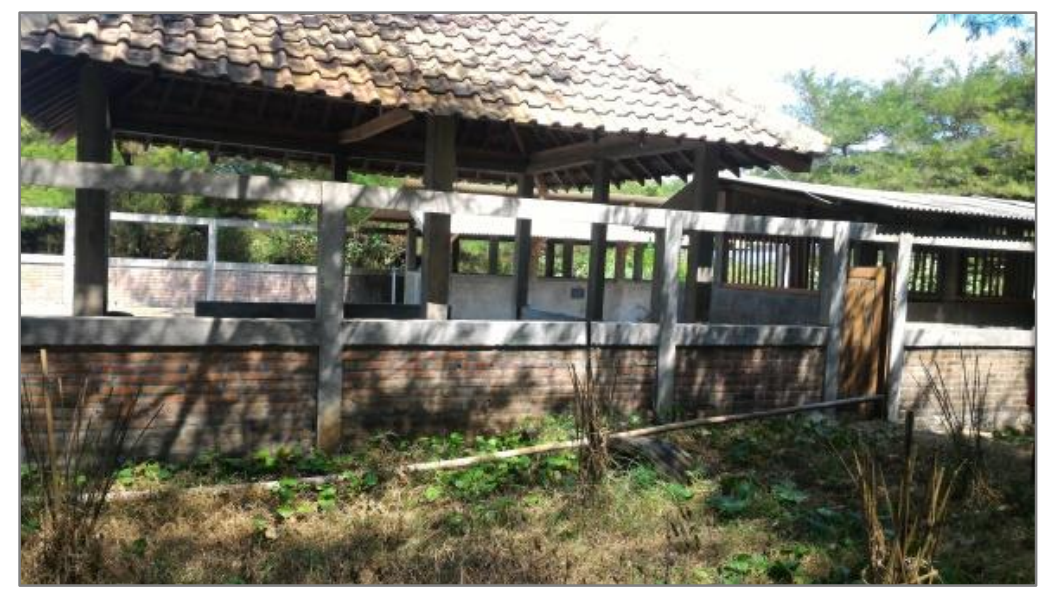

Gambar 3. Konservasi penyu di Pesisir Samas

Pengelolaan penyu dilakukan secara semi alami oleh pengelola. Telur penyu dipindahkan ke kolam penampungan dan pemeliharaan yang telah disediakan pengelola. Kegiatan ini bertujuan untuk menjaga keamanan penetasan. Pengelola juga melakukan 
perawatan terhadap penyu-penyu yang terluka. Usaha pengelola ini didukung oleh banyak pihak, diantaranya DKP dan Balai Konservasi Sumberdaya Alam

\section{d. Penghilangan PSK}

Wisata malam potensial muncul di berbagai kawasan pesisir, tidak hanya di kawasan pantai samas, tetapi juga kawasan pantai-pantai lainnya. Wisata malam ini dinilai sebagai penyakit sosial. Penyelengaraannya sendiri ilegal atau tidak berijin. Wisata malam kawasan pesisir samas umunya dikelola oleh orang luar daerah atau bukan penduduk asli samas.

Berdasarkan hasil wawancara, keberadaan wisata malam ini jelas mengganggu. Citra daerah dimata luar kemudian menjadi buruk dan mengganggu ketenangan warga karena tidak jarang warga asli bersitegang dengan pelanggan hingga memicu bentrok. Praktik wisata malam juga menyebabkan menurunnya jumlah pengunjung pantai samas, sebagaimana dituturkan Sarijan dalam koransindo.com.

Masyarakat setempat dan pemerintah telah melakukan berbagai upaya untuk menghilangkan praktik prostitusi ini. Upaya tersebut diantaranya peneguran, hingga razia yang rutin dilaksanakan, namun hasilnya tidak optimal. Kegiatan keagamaan pun telah coba dilakukan masyarakat untuk membina para pelaku prostitusi, dan hasilnya tetap sama saja. Hingga saat ini memang belum ada upaya optimal untuk menghilangkan praktik prostitusi ini.

\section{Strategi Revitalisasi Pantai Samas}

\subsection{Zonasi Kawasan Wisata Pantai Samas}

Pemulihan kawasan wisata Pesisir Samas melalui pembangunan dan kebijakan lainnya perlu memperhatikan daya dukung dan daya tampung lingkungannya. Hal ini untuk mencegah pembangunan yang bermaksud baik akan menimbulkan dampak buruk disisi lain. Zonasi wilayah merupakan salah satu cara untuk mengakomodir hal tersebut.

Pembuatan peta zonasi di penelitian ini menggunakan dasar bentuklahan. Bentuklahan merupakan kenampakan permukaan bumi yang memiliki proses, material, dan morfologi yang seragam (Strahler, 2011). Oleh karena itu, satu satuan bentuklahan akan memiliki potensi sumberdaya alam dan bencana yang cenderung homogen. Aplikasi dari konsep ini adalah setiap bentuklahan di Pesisir Samas akan memiliki tingkat pemanfaatan yang berbeda agar lestari.

Peta Zonasi Kawasan Wisata Pesisir Samas dibagi menjadi 3 zona (Gambarr 4), yaitu.

a. Zona Inti yang memiliki fungsi utama sebagai pusat kegiatan wisata, seperti melihat pemandangan laut, bermain ombak, bersantai di gisik, wisata perahu di laguna.

b. Zona Pendukung memiliki aktivitas yang masih berhubungan dengan zona inti dan berfungsi mendukung kegiatan pada zona inti, seperti mobil ATV, dokar, kolam renang, kuliner khas, wahana bermain.

c. Zona Pelayanan yang memiliki fungsi melayani aktivitas zona inti dan zona pendukung, seperti hotel/penginapan, kantor pengurus, laboratorium penelitian. 


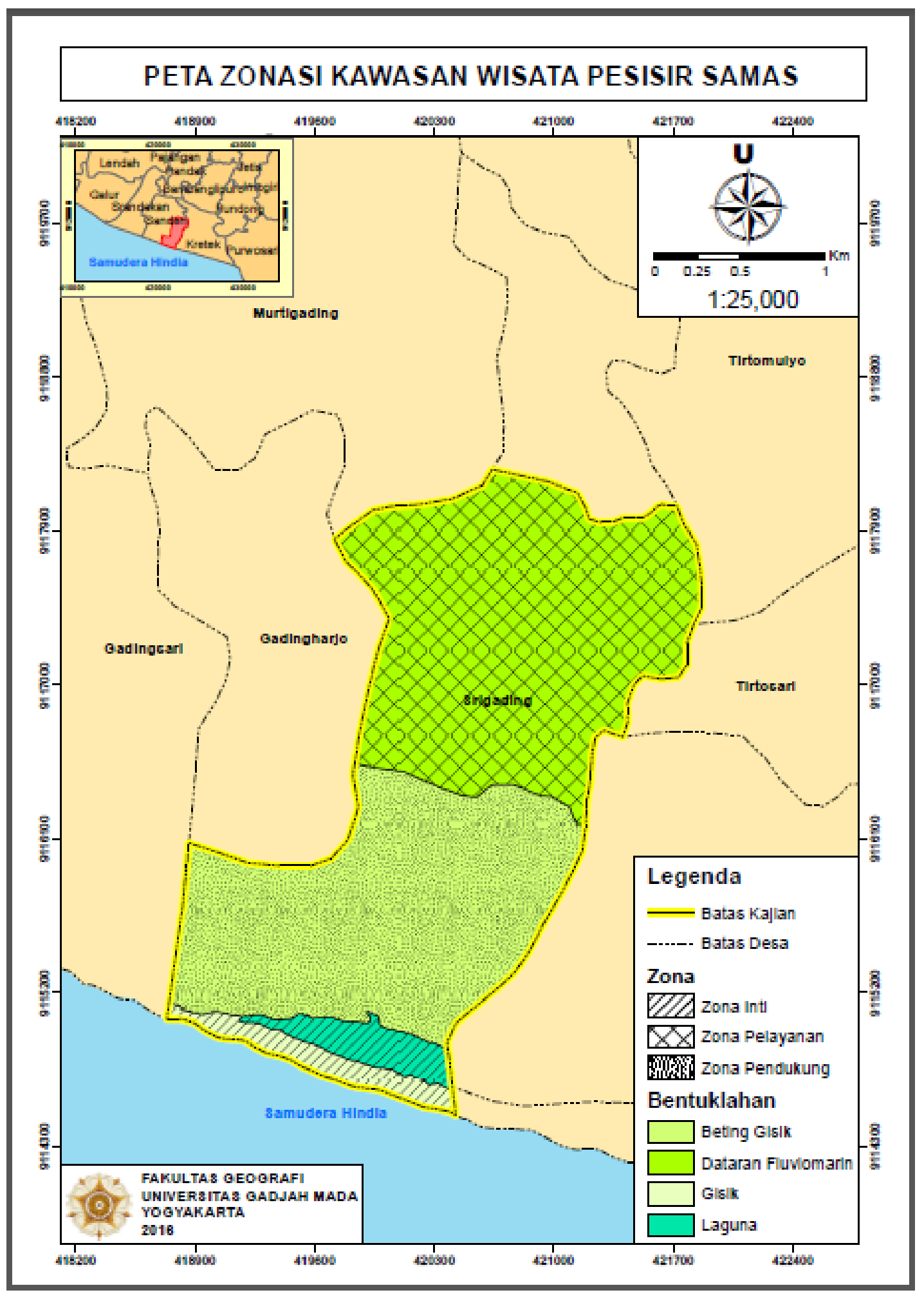

Gambar 4. Peta Zonasi Kawasan Wisata Pesisir

Setiap kegiatan yang direncakan pada zonasi diatas tidak lepas dari karakteristik bentuklahan yang ada. Zona inti berada pada bentuklahan gisik dan laguna. Karakteristik 
kedua bentuklahan ini adalah memiliki proses marin yang paling kuat dibandingkan lainnya. Oleh karena itu, kegiatan utama wisata berada di zona ini. Selain itu, zona ini memiliki ancaman bahaya yang paling tinggi, seperti sapuan ombak dan banjir Sungai Opak. Oleh karena itu, jenis kegiatan dan prasarana yang ada di zona ini bersifat mudah dipindahkan ketika terjadi bahaya.

Zona pendukung berada di bentuklahan beting gisik. Karkteristik dari zona ini adalah aktivitas gelombang yang tidak langsung berpengaruh dan gisik yang berasal dari pengendapan masa lalu. Oleh karena itu, kegiatan dan infrastruktur yang berada disini dapat tergolong permanen. Zona pendukung berada di bentuklahan dataran fluviomarin. Karakteristik zona ini adalah proses marin sudah bercampur dengan proses fluvial, sehingga ancaman bahaya dari proses marin jauh lebih minimal. Potensi sumberdaya yang ada berupa tanah yang lebih subur dan kedalaman airtanah yang relatif lebih rendah. Oleh karean itu, kegiatan yang ada disini lebih cenderung mengarah ke aspek pribadi, seperti permukiman penduduk, pertanian, dan perkantoran kawasan wisata.

Peta Zonasi Kawasan Wisata Pantai Samas dibuat sebagai landasan atau arahan penataan kawasan ini. Selain itu, peta ini dapat digunakan sebagai dasar pembuatan zonasi wilayah pesisir detail yang diatur dalam UU No.1 Tahun 2014. Hal yang perlu didiskusikan dalam pembuatan zonasi di penelitian ini adalah belum dipertimbangkannya aspek sosial seperti kearifan lokal masyarakat dan struktur demografi dan mata pencaharian masyarakat. Selain itu, integrasi dari RTRW yang telah dibuat oleh BAPPEDA juga perlu dilakukan.

\subsection{Upaya Revitalisasi Pantai Samas yang Dapat Ditempuh}

Dilihat dari kondisi fisiknya, pantai samas memiliki potensi wisata yang cukup besar seperti pantai dengan ombaknya yang besar, delta-delta sungai dan danau air tawar yang membentuk telaga-telaga dan laguna. Telaga-telaga tersebut juga digunakan untuk pengembangan perikanan, penyu dan udang galah. Kondisi fisik yang demikian membawa Pantai Sama pada masa kejayaan sebagai wisata pantai paling terkenal di Yogyakarta pada tahun 1985. Saat ini kejayaan pantai samas sudah tidak terlihat lagi seiring dengan semakin berkembangnya pembangungan serta akibat adanya bencana alam dan bencana sosial yang terjadi di Pantai Samas. Berdasarkan potensi wilayahnya yang besar maka revitalisasi Pantai Samas dirasa perlu dilakukan untuk mengembalikan kejayaan pantai samas. Peran pemerintah dan masyarakat sekitar pantai Samas sangat diperlukan dalam membantu proses revitalisasi Pantai Samas. Beberapa strategi revitalisasi yang dapat diupayakan di Pantai Samas diantaranya.

\section{a. Penguatan Organisasi Pengelola Wisata}

Pengelolaan wisata pantai samas yang saat ini masih belum terorganisir dengan baik perlu diperkuat keberadaannya supaya wisata Pantai Samas memiliki daya tarik lebih dibandingkan pantai-pantai lain di Bantul. Kendala kurangnya sumberdaya manusia dalam pengelolaan wisata pantai dapat diatasi dengan memberikan sosialisasi kepada 
masyarakat lokal untuk ikut serta dalam mengambalikan kejayaan pantai Samas. Adanya BUMDES (Badan Usaha Milik Desa) dapat menjadi wadah bagi organisasi pengelola wisata Pantai Samas.

\section{b. Pengembalian Citra Pantai Samas}

Pantai Samas dengan segala potensinya dapat dikembangkan dengan beberapa cara sebagai berikut.

\section{i. Menata tempat penjualan ikan seperti di Pantai Depok.}

Pantai Samas sebagai tempat berlabuhnya nelayan-nelayan pencari ikan seperti pantai-pantai lain di Bantul dapat menjadi modal dalam penataan tempat penjualan ikan segar di Pantai Samas. Letak Pantai Samas yang lebih strategis karena dekat dengan loket masuk menjadikan Pantai Samas lebih strategis dibandingkan pantai lain sehingga dapat menarik pengunjung untuk membeli ikan-ikan segar di Pantai Samas ketika berwisata di Pantai Samas.

\section{ii. Pengelolaan laguna Pantai Samas.}

Laguna pantai Samas dengan pesona yang memikat pengunjung dapat menjadi daya tarik bagi pengunjung. Pengembangan wisata air seperti pemancingan dan penggunaan kapal nelayan lokal ketika tidak digunakan melaut untuk mengantar wisatawan menjelajahi laguna. Wisata disekitar laguna sebenarnya telah terbentuk, hanya saja saat ini pengelolaannya masih dirasa kurang. Keberadaan sampah yang masih banyak terlihat di sekitar wisata laguna dan kurangnya fasilitas umum disekitar tempat wisata menjadikan wisata laguna Pantai Samas masih harus dikelola lebih baik.

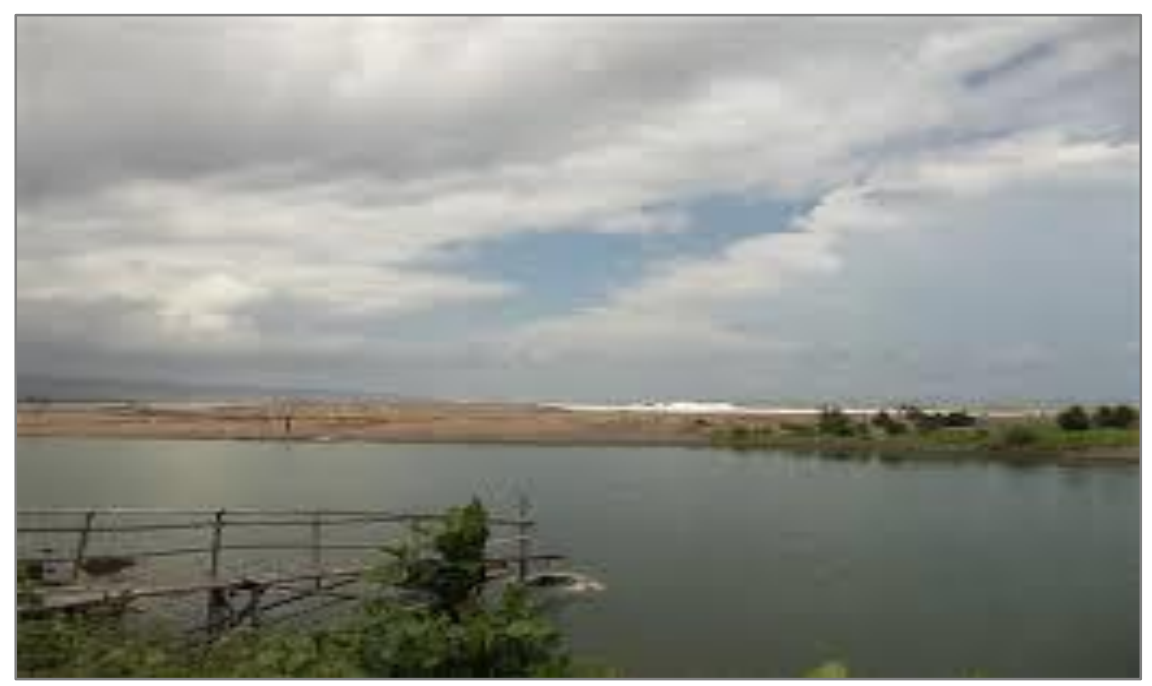

Gambar 5. Laguna Pantai Samas

\section{iii. Pengembangan penangkaran penyu.}

Penangkaran penyu ini sebenarnya sudah berdiri sejak tahun 2000. Namun keberadaan konservasi penyu di Pantai Samas belum digunakan sebagai tempat wisata. Penangkaran penyu yang ada sekarang masih sangat sederhana berupa bangunan dan beberapa penyu dan telur penyu di dalamnya. Tidak banyak yang 
mengetahui bahwa bangunan tersebut sebagai tempat penangkaran penyu. Untuk mewujudkan keinginan pengelola penangkaran penyu yaitu sebagai sarana wisata edukasi maka pengelolaannya perlu diperbaiki. Beberapa hal dapat dilakukan untuk mewujudkan penangkaran penyu sebagai wisata edukasi, seperti dibuatnya papan atau poster terkait informasi penangkaran penyu dan jenis-jenis penyu serta pembangunan sebuah bangunan sebagai area diskusi bagi para pengunjung wisata penangkaran penyu. Para pengelola penangkaran ini dapat menjadi narasumber dalam kegiatan diskusi tersebut.

Beberapa upaya revitalisasi wisata Pantai Samas membutuhkan dukungan dari pemerintah, akademisi, dan masyarakat sekitar. Peran pemerintah dapat membantu dari segi pendanaan untuk pembangunan serta sosialiasai kepada masyarakar sekitar tentang pengelolaan yang tepat dibantu dengan pihak akademisi. Melibatkan masyarakat dapat menumbuhkan rasa tanggungjawab dan rasa memiliki untuk menjaga kawasan wisata agar tetap nyaman. Selain itu juga pendapatan dari wisata dapat membantu masyarakat secara ekonomi. Promosi wisata juga sangat diperlukan untuk mendorong wisatawan mengunjungi Pantai Samas. Proses revitalisasi ini perlu memperhatikan aspek lingkungan alam dan sosial supaya pembangunan dan pengelolaan tidak merusak ekosistem.

\section{Kesimpulan dan Rekomendasi}

\subsection{Kesimpulan}

Kesimpulan dari penelitian ini adalah sebagai berikut.

1. Penurunan pengunjung Pantai Samas disebabkan oleh tiga hal besar, yaitu daya tarik pantai yang kurang (disebabkan oleh kurangnya fasilitas dan infrastuktur serta abrasi yang menerjang parah), citra pantai yang buruk akibat maraknya prostitusi, dan munculnya obyek wisata pantai yang lebih menarik disekitarnya.

2. Pengelolaan lingkungan yang telah dilakukan di Pantai Samas terdiri dari menambah daya tarik wisata (penanaman cemara udang, pendirian wisata pengklik, dan pembangunan konservasi penyu) dan penghilangan citra buruk dengan berusaha menghentikan kegiatan prostirusi. Usaha pengelolaan tersebut masih belum efektif dan kurang serius yang dapat dilihat dari tidak adanya perubahan tampilan dan masih sepinya Pantai Samas.

3. Langkah-langkah strategis untuk merevitalisasi Pantai Samas, yaitu melakukan penataan lokasi wisata yang sesuai peruntukannya (menambah daya tarik wisata serta fasilitas dan infrastuktur), memeperkuat organisasi pengelola wisata dari masyarakat lokal, dan melakukan promosi yang masif.

\subsection{Rekomendasi}

Rekomendasi dari penelitian ini adalah sebagai berikut.

1. Zonasi wilayah pesisir yang sesuai UU No 27 Tahun 2007 mengenai Pengeloaan Pesisir dan Pulau-Pulau Kecil harus segera dilakukan. Hal ini dikarenakan Pesisir Samas dan 
sekitarnya berpotensi menjadi sentral industri dengan dibangunnya jalan nasional lintas selatan. Peta zonasi dibutuhkan untuk mengawal pembangunan yang kelak terjadi tidak menimbulkan degradasi lingkungan.

2. Pengembangan atau revitalisasi Pantai Samas harus melibatkan empat komponen penting, yaitu pemerintah, masyaraakat sipil (lokal), akademisi, dan investor. Revitalisasi yang dilakukan harus memperhatikan keberlanjuta (lingkungan, sosial budaya, dan ekonomi).

\section{Daftar Pustaka}

Adenan, Dermawan. 2002. Kajian Faktor Sosial Ekonomi dan Budaya dalam Upaya Peningkatan Pendapatan Buruh Nelayan Gillnet di Kabupaten Bantul Provinsi Daerah Istimewa Yogyakarta. Tesis. Semarang: Pascasarjana Magister Manajemen UNDIP.

Amin, Miftachul. 2011. Tugas Akhir Dasar Program Perencanaan dan Perancangan Arsitektur (DP3A): "Perencanaan Hotel Resort di Kawasan Wisata Pantai Menganti, Kebumen". Surakarta: Jurusan Teknik Arsitektur, Fakultas Teknik, UMS.

Anonim. Tanpa tahun. Modul Pengendalian dan Pemulihan Degradasi Ekosistem Pertanian.

Anonim. Tanpa tahun. Modul UPI: Kerusakan Lingkungan Biogeofisik.

Anonim. Tanpa tahun. Modul USU: Degradasi Lingkungan.

Anonim. Undang-undang No 27 tahun 2007 mengenai "Batasan Wilayah Pesisir".

BPBD. 2013. Data Abrasi Pantai Samas oleh BPBD Kabupaten Bantul per September 2013. Bantul: BPBD Kabupaten Bantul.

Dahuri, R. et al. 1998. Penyusunan Konsep Pengelolaan Sumber daya Pesisir dan Lautan yang Berakar dari Masyarakat Kerjasama Ditjen Bangda dengan Pusat Kajian Sumber daya Pesisir dan Lautan. Laporan Akhir. Bandung:IPB

Departemen Energi dan Mineral. 2006. Laporan Penyelidikan Geologi dan Geofisika Kelautan Perairan Sebatik, Kabupaten Nunukan Propinsi Kalimantan Timur. Kalimantan Timur: Pusat Penelitian dan Pengembangan Geologi Kelautan.

Edlund L, Korn E . 2002. A Teory of Prostitution, Journal of Political Economy. University of Chicago: Sektor Pariwisata, Seni, dan Budaya APBD Kabupaten Bantul

Garrison. 2011. Akutansi Manajerial. Jakarta: Salemba Empat.

Nasrudin,Hasyim. Tanpa tahun. Sumbangan Aktivitas Usaha Tani Pekarangan Terhadap Pendapatn Rumahtangga Desa Srigading kecamtan Sanden Kabupaten Bantul. 
Kusharjani, Sri Harteti, Achmad Fahrudin, Fredinan Yulianda dan Armin Ambrosius Hutabarat. 2009. Pengelolaan Pesisir dan Laut Secara Terpadu. Penerbit: Pusdiklat Kehutanan, Departemen Kehutanan Republik Indonesia, SECEM dan Korea International Cooperation Agency.

Nontji, A. 2002. Laut Nusantara. Jakarta: Djambatan.

Ongkosongo, O. 2004. Perubahan Lingkungan di Wilayah Pesisir. Stuktur Fisik dan Dinamik Pesisir. Makalah Workshop: Deteksi, Mitigasi dan Pencegahan Degradasi Lingkungan Pesisir dan Laut Indonesia.

Saputra, dkk. 2013. Pengantar Kebutuhan Dasar Manusia. Jakarta: Binarupa.

Strahler. 2011. Modern Physical Geography.

Suabuana. 2008. Degradasi Nilai dan Moral dalam Tinjauan Mata Kuliah PLSBT.

\section{LAMAN}

http://aplikasi.mgi.esdm.go.id/perpustakaan/pdf/36-Sebatik.pdf. Diakses pada Rabu, 20 Mei 2016 pukul 10.50 WIB.

http://repository.usu.ac.id/bitsream/123456789/4/Chapter\%20II.pdf. Diakses pada Senin, 18 Mei 2016 pukul $21.30 \mathrm{WIB}$

http://file.upi.edu/Direktori/FPIPS/JUR._PEND._GEOGRAFI/197210242001121.BAGJA_WAL UYA/Pengelolaan_Lingkungan_Hidup_untuk_Tk_SMA/Bab_10_Masalah_lingkunganbi ogeofisik.pdf. Diakses pada Senin, 18 Mei 2016 pukul 20.45

http://file.upi.edu/Direktori/FPIPS/M_K_D_U/196006161986031.CIK_SUABUANA/Degradasi_ Nilai_dan_Moral_dalam_Tinjauan_Mata_Kuliah_PLSBT.pdf. Diakses pada Senin, 18 Mei 2016 pukul 20.15 WIB.

http://m.inilah.com/news/detail/2266413/warga-bantul-kelola-wisata-pesisir-pantai-samas.

Diakses pada 6 Juni 2016 pukul 14.30 WIB.

http://kec-sanden.bantulkab.go.id. Diakses pada Rabu, 08 Juni 2016 pukul 20.37 WIB

http://koran-sindo.com/news.php? $r=5 \& n=137 \&$ date $=2015-11-26$. Diakses pada 6 Juni 2016 pukul 15.35 WIB

http://lib.geo.ugm.ac.id/ojs/index.php/jbi/article/viewFile/194/190. Diakses pada Rabu, 08 Juni 2016 pukul 21.03 WIB

http://www.litbang.pertanian.go.id/buku/membalik-kecenderungan-degrad/BAB-II-1.pdf.

Diakses pada Senin, 18 Mei 2016 pukul 19.50 WIB. 
http://www.merdeka.com/khas/cemara-udang-bawa-banyak-manfaat-bagi-petani-tepi-pantaiifclorg.html. Diakses pada 6 Juni 2016 pukul 14.00 WIB

http://www.republika.co.id/berita/shortlink/93370. Diakses pada 6 Juni 2016 pukul 16.05 WIB. 